Article

\title{
Mechanism for Higher Tolerance to and Lower Accumulation of Arsenite in NtCyc07- Overexpressing Tobacco
}

\author{
DongGwan Kim ${ }^{+}$,, Ramin Bahmani ${ }^{+}(\mathbb{D}$, Mahsa Modareszadeh and Seongbin Hwang * \\ Department of Bioindustry and Bioresource Engineering, Department of Molecular Biology and Plant \\ Engineering Research Institute, Sejong University, Seoul 05006, Korea; kimdg@sejong.ac.kr (D.K.); \\ rbahmani@snu.ac.kr (R.B.); mmodareszadeh@sju.ac.kr (M.M.) \\ * Correspondence: sbhwang@sejong.ac.kr; Tel.: +82-2-3408-3642 \\ + These authors contributed equally to this work.
}

Received: 12 October 2020; Accepted: 30 October 2020; Published: 3 November 2020 updates

\begin{abstract}
Arsenite [As(III)] is a highly toxic chemical to all organisms. Previously, we reported that the overexpression of $\mathrm{NtCyc07}$ enhanced $\mathrm{As}(\mathrm{III})$ tolerance and reduced $\mathrm{As}(\mathrm{III})$ accumulation in yeast (Saccharomyces cerevisiae) and tobacco (Nicotiana tabacum). To understand a mechanism for higher $\mathrm{As}(\mathrm{III})$ tolerance and lower $\mathrm{As}(\mathrm{III})$ accumulation in $\mathrm{NtCyc07-overexpressing} \mathrm{tobacco,} \mathrm{we} \mathrm{examined}$ the expression levels of various putative As(III) transporters (aquaporin). The expressions of putative As(III) exporter NIP1;1, PIP1;1, 1;5, 2;1, 2;2, and 2;7 were enhanced, while the expressions of putative As(III) importer NIP3;1, 4;1, and XIP2;1 were decreased, contributing to the reduced accumulation of $\mathrm{As}$ (III) in $\mathrm{NtCyc07-overexpressing} \mathrm{tobacco.} \mathrm{In} \mathrm{addition,} \mathrm{the} \mathrm{levels} \mathrm{of} \mathrm{oxidative} \mathrm{stress} \mathrm{indicators}$ $\left(\mathrm{H}_{2} \mathrm{O}_{2}\right.$, superoxide and malondialdehyde) were lower, and the activities of antioxidant enzymes (catalase, superoxide dismutase and glutathione reductase) were higher in $\mathrm{NtCyc07-tobacco} \mathrm{than}$ in the control tobacco. This suggests that the lower oxidative stress in transgenic tobacco may be attributed to the higher activities of antioxidant enzymes and lower As(III) levels. Taken together, the overexpression of $\mathrm{NtCyc07}$ enhances $\mathrm{As}$ (III) tolerance by reducing As(III) accumulation through modulation of expressions of putative As(III) transporters in tobacco.
\end{abstract}

Keywords: aquaporin; arsenic; Cyc07; NIP; PIP; ROS; tobacco

\section{Introduction}

Arsenic is present in the land, air and ground water, and acts as a toxic substance to humans, animals and plants [1]. In most cases, arsenic enters humans through drinking water or crops which absorb arsenic that dissolves in rainwater and flows into the environment [2]. The concentration that does not harm humans is less than 10 50 ppb [3], and over than this concentration, the acute and chronic arsenic toxicity will appear [4]. The main toxic effects to humans are cancer $[5,6]$, heart disease (hypertension-related cardiovascular disease) [7], stroke (cerebrovascular diseases) [8], chronic respiratory disease [9] and diabetes [10].

Major forms of inorganic arsenic in the environment, $\mathrm{As}(\mathrm{III})$ (arsenite) and $\mathrm{As}(\mathrm{V})$ (arsenate), can enter plants through high-affinity Pi transporters and the Nod26-like Intrinsic Protein (NIP) subfamily of aquaporins, respectively [11-13]. Plant aquaporins can be categorized into four subgroups: Plasma membrane Intrinsic Proteins (PIPs), Nod26-like Intrinsic Proteins (NIPs), Tonoplast Intrinsic Proteins (TIPs) and Small Basic Intrinsic Proteins (SIPs). The NIPs are localized at plasma/intracellular membranes, while SIPs are at the endoplasmic reticulum [14]. Aquaporins participate in transportation of water, ammonia, arsenic, boric acid, glycerol, metalloids, nitric oxide, and reactive oxygen 
species [15-20]. All reported NIPs have As(III) influx activities [11,13,21-26]; the knockout Arabidopsis of AtNIP1;1 and AtNIP7;1 displayed higher tolerance to and lower accumulation of As(III) [13,27]. The nip1;2 and nip5;1 mutants of Arabidopsis accumulated less As(III), while they did not show a higher tolerance to As(III) [27]. In addition, OsNIP3;2 is involved in As(III) uptake in rice since a knockout mutant showed lower accumulations of As(III) in its roots, compared to WT plants [28]. It has been reported that, among NIPs, AtNIP5;1 and AtNIP6;1 of Arabidopsis, OsNIP2;1 (OsLsi1) and OsNIP3;2 of rice, and LjNIP5;1 and LjNIP6;1 of Lotus japonicus are involved in the bi-directional transport (both uptake and export) of As(III) in yeast or plants [11]. Among PIPs, the overexpression of OsPIP2;4, OsPIP2;6 and OsPIP2;7 enhanced As(III) tolerances in Arabidopsis. Interestingly, OsPIP2;6-expressing Arabidopsis exhibited higher activities in As(III) uptake and export in roots in response to short-term (4 h) exposure to As(III) [29]. Recently, 88 aquaporin genes were identified in Nicotiana tabacum genome and assigned into five subfamilies: 34 plasma membrane intrinsic proteins (PIPs); 27 tonoplast intrinsic proteins (TIPs); 20 nodulin26-like intrinsic proteins (NIPs); three small basic intrinsic proteins (SIPs); four uncharacterized $X$ intrinsic proteins (XIPs) [30].

The $\mathrm{Cyc07}$ gene was first reported in Catharanthus roseus [31]. Cyc07 mRNA was detected specifically in the $S$ phase of synchronous cultures as well as in intact plants, and was found mainly in the meristem zone of root tips [32]. Cyc07 has a domain of ribosomal S3Ae [32]. Tobacco Cyc07 ( $\mathrm{NtCyc07)} \mathrm{was} \mathrm{cloned} \mathrm{and} \mathrm{identified} \mathrm{to} \mathrm{be} \mathrm{involved} \mathrm{in} \mathrm{arsenite} \mathrm{tolerance} \mathrm{by} \mathrm{reducing} \mathrm{As} \mathrm{accumulation}$ through interacting with ACR1 which is a transcription factor of the arsenite exporter ACR3 in yeast [33]. In addition, the overexpression of $\mathrm{NtCyc07}$ in tobacco enhanced arsenite tolerances by decreasing As accumulation [34]. Tobacco has a single gene of $\mathrm{NtCyc07.} \mathrm{Regarding} \mathrm{genes} \mathrm{involved} \mathrm{in} \mathrm{arsenic}$ tolerance in tobacco, it was only reported that the overexpression of tobacco phytochelatin synthase (NtPCS1) enhances arsenite tolerances in yeast [35] and tobacco [36].

In this report, to understand a mechanism for higher tolerance to and lower accumulation of $\mathrm{As}(\mathrm{III})$ in $\mathrm{NtCyc07-expressing} \mathrm{tobacco,} \mathrm{we} \mathrm{have} \mathrm{examined} \mathrm{expressions} \mathrm{of} \mathrm{putative} \mathrm{As(III)} \mathrm{transporters}$ NIPs and PIPs, ROS (reactive oxygen species) levels and antioxidant enzyme activities. We found that $\mathrm{NtCyc07}$ enhanced $\mathrm{As}$ (III) tolerances by decreasing As(III) accumulations through regulation of expressions of putative As(III) transporters. In addition, $\mathrm{NtCyc07-tobacco} \mathrm{displayed} \mathrm{a} \mathrm{lower} \mathrm{oxidative}$ stress and higher activities of antioxidant enzymes, which may be ascribed to the lower accumulation of As(III).

\section{Results and Discussion}

\subsection{NtCyc07-Overexpressing Tobacco Displayed Higher Tolerance to and Lower Accumulation of As(III)}

We have examined again As(III) tolerance and accumulation in a vector only expressing control (pBI121) and $\mathrm{NtCyc07-overexpressing} \mathrm{(} \mathrm{NtCyc07-3}$ and $\mathrm{NtCyc07-6)}$ tobacco since we challenged plants with $30 \mu \mathrm{M}$ As(III) which is higher than previously used $15 \mu \mathrm{M}$ [34] to induce a remarkable difference in As(III) tolerance between control and transgenic plants. As shown in Figure 1a,b, NtCyc7-tobacco exhibited a higher tolerance to As(III) than control plants, and control and transgenic plants were healthy based on green colors/chlorophylls even with enhanced As(III) concentrations. In addition, $\mathrm{As}(\mathrm{III})$ accumulation was lower in $\mathrm{NtC} y \mathrm{C} 07$-tobacco than in control plants (Figure 1c), suggesting that the higher As(III) tolerance in transgenic tobacco is ascribed to the reduced level of As(III).

Supporting our results, many studies have reported that the higher metal tolerance is ascribed to the lower accumulation of metal in plants. Indian mustard (Brassica juncea) with moderate expression of AtPCS1 (Phytochelatin Synthase 1 of Arabidopsis) exhibited increased tolerance to and reduced accumulation of $\mathrm{Cd}$ and $\mathrm{Zn}$ [37]. Overexpression of tobacco $\mathrm{Cyc} 07$ (cell cycle-related protein 7) enhanced As(III) tolerance and reduced As(III) accumulation in tobacco [34]. The overexpression of tobacco PIC1 (Permease In Chloroplast 1) in tobacco enhanced Cd tolerance and reduced Cd content [38]. Overexpression of tobacco $\mathrm{Hb} 1$ (non-symbiotic class 1 hemoglobin 1) increased Cd tolerance and decreased Cd level in tobacco [39] and Arabidopsis [40]. The overexpression of CsMTP8 (Metal 
Transport Protein 8 of tea plant Camellia sinensis) enhanced Mn tolerance and reduced Mn accumulation in Arabidopsis [41]. Transgenic tobacco overexpressing tobacco UBC1 (ubiquitin-conjugating protein 1) displayed higher tolerance to and lower level of Cd [42]. Overexpression of WRKY13 enhanced a Cd tolerance and reduced $\mathrm{Cd}$ accumulation by increasing the expression of Cd exporter PDR8 [43]. Transgenic rice which expresses TaCNR2 (Cell Number Regulator 2 of wheat Triticum aestivum) showed an enhanced $\mathrm{Cd}$ tolerance and a reduced Cd level [44]. Overexpression of tobacco UBQ2 (ubquitin-extension protein 2) in tobacco and Arabidopsis increased a Cd tolerance and reduced a $\mathrm{Cd}$ level [45]. Transgenic Arabidopsis overexpressing miRNA156 displayed higher Cd tolerance and lower Cd level [46].

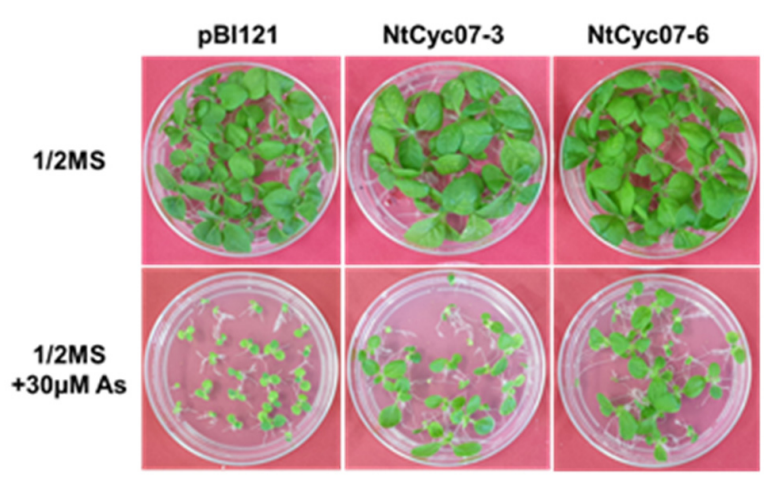

(a)

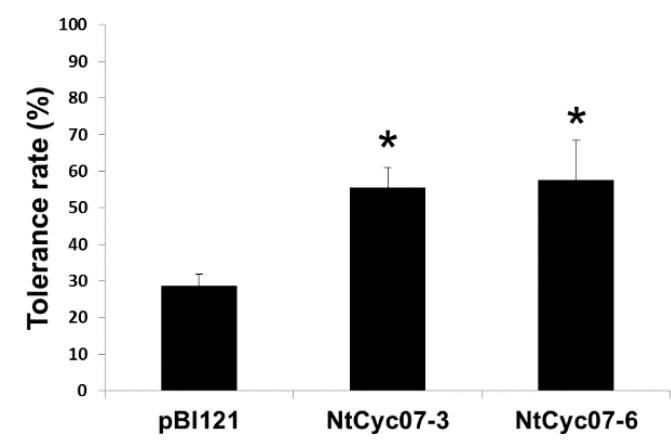

(c)

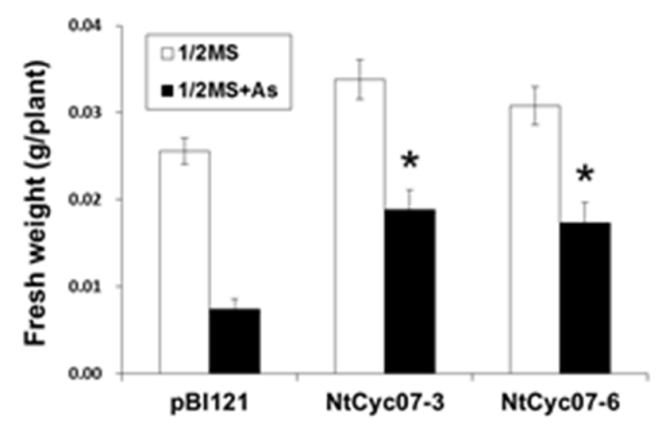

(b)

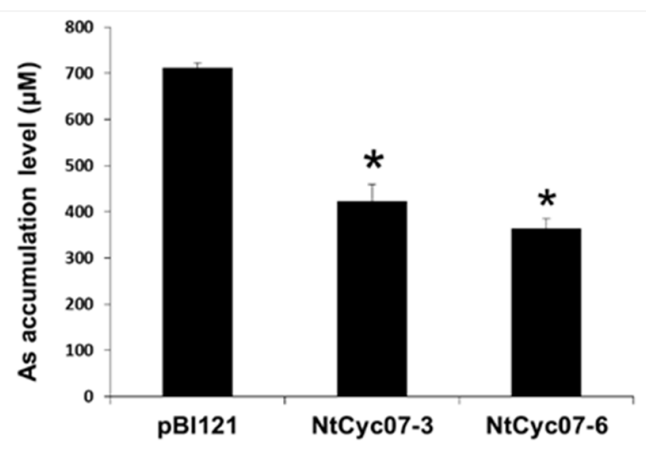

(d)

Figure 1. As(III) tolerance and level in $\mathrm{NtCyc07-expressing} \mathrm{tobacco.} \mathrm{(a)} \mathrm{Comparison} \mathrm{of} \mathrm{morphology}$ and $\mathrm{As}(\mathrm{III})$ tolerance in transgenic tobacco expressing $p B I 121$ only (control) and $\mathrm{NtCyc07} \mathrm{(NtCyc07-3}$ and NtCyc07-6) in response to As(III) stress. All plants were germinated and grown for 3 weeks on 1/2 Murashige and Skoog medium (MS) agar plates without (upper) and with (lower) $30 \mu \mathrm{M} \mathrm{As(III).}$ (b) Fresh weights of tobacco shown in (a). (c) As(III) tolerance rates of tobacco shown in (a,b). (d) As(III) accumulations in whole seedlings of control and $\mathrm{NtCyc07}$ tobacco shown in (a). 1/2 MS indicates a control (no As(III) treatment). Each value corresponds to the means of three independent experiments, and error bars indicate standard errors. Asterisks indicate significant differences between control and transgenic tobacco $(p \leq 0.05)$.

\subsection{Expressions of Putative As(III) Transporters Were Modulated in NtCyc07-Tobacco}

Previously, we have reported that $\mathrm{NtCyc07-overxpressing} \mathrm{tobacco} \mathrm{displayed} \mathrm{a} \mathrm{higher} \mathrm{As}(\mathrm{III})$ tolerance and the lower accumulation of As(III), compared with control plants [34]. To understand a molecular mechanism for the higher As(III) tolerance and lower accumulation of As(III)

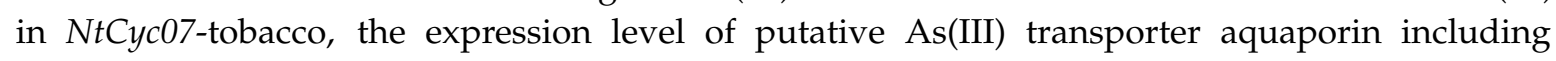
NtNIP1;1 (XP_016487110.1), NtNIP2;1 (XP_016451246.1), NtNIP3;1 (XP_016460638.1), NtNIP4;1 (XP_016486634.1), NtPIP1;1 (NP_001313131.1), NtPIP1;5 (AAB81601.1), NtPIP2;1 (AF440272.1), NtPIP2;2 (NM_001325404.1), NtPIP2;7 (NP_001313061.1), NtPIP2;17 (NP_001312464.1), NtXIP1;1 $\alpha$ 
(NP_001312796) and NtXIP2;1 (XP_016489264.1), were examined. To date, the involvement of aquaporin in the As(III) transport has never been reported in tobacco. Therefore, the putative As(III) transporters were selected among NIPs and PIPs based on protein sequences showing differences in homology, substrate specificity determining positions (SDPs), and plasma membrane localization [30].

As shown in Figure 2a-d, among NIPs, NIP1;1 expression was higher and expressions of NIP3;1 and NIP4; 1 were lower in NtCyc07-tobacco than in control plants, while the expression level of NIP2;1 was not different from that of control. This suggests that NIP1;1, NIP3;1 and NIP4;1 may be involved in the lower accumulation of $\mathrm{As}(\mathrm{III})$ in $\mathrm{NtCyc07-expressing} \mathrm{tobacco.} \mathrm{In} \mathrm{support} \mathrm{of} \mathrm{this,} \mathrm{SDP} \mathrm{data} \mathrm{show}$ that NIP1;1, NIP3;1 and NIP4;1 had a As specificity but NIP2;1 did not [30]. Based on these data, it is assumed that NIP1;1 has a higher activity of As(III) exporter than of As(III) importer, while NIP3;1 and NIP4;1 has a higher activity of As(III) importer. Therefore, the modulated expressions of these aquaporins may contribute to the reduced accumulation of As(III) in transgenic tobacco.

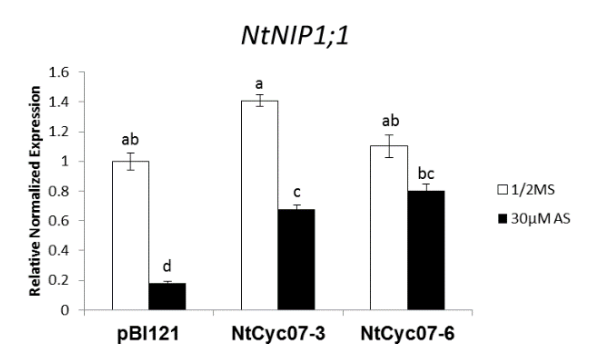

(a)

NtNIP3;1

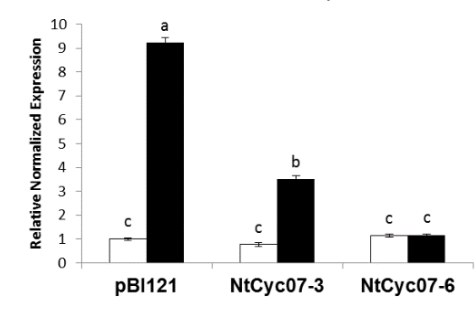

(c)

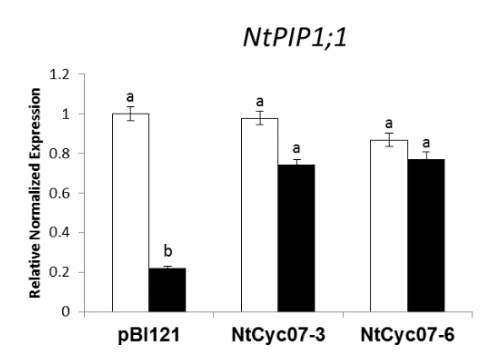

(e)

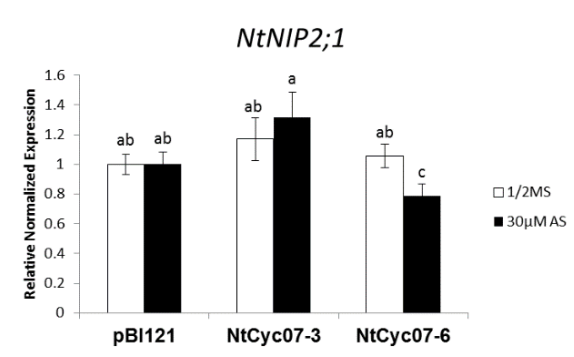

(b)

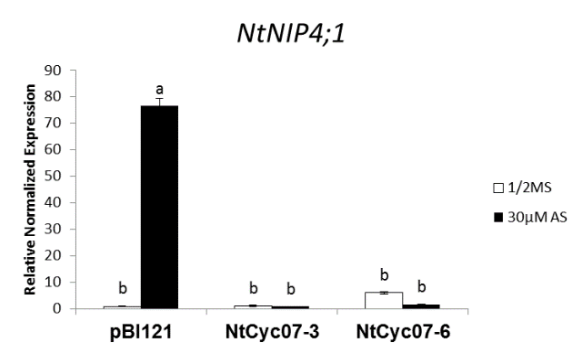

(d)

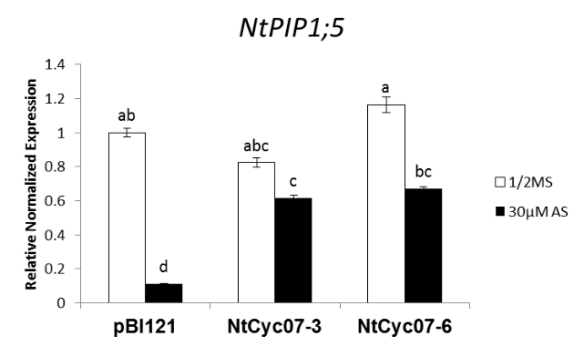

(f)

Figure 2. Cont. 


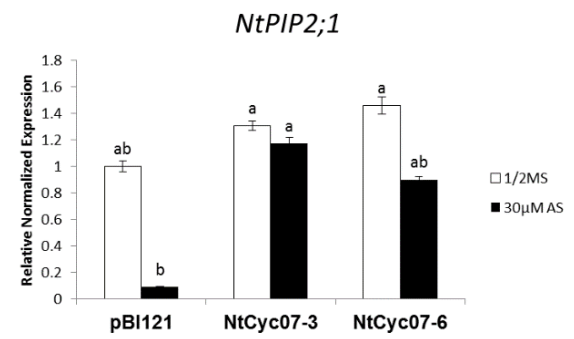

(g)

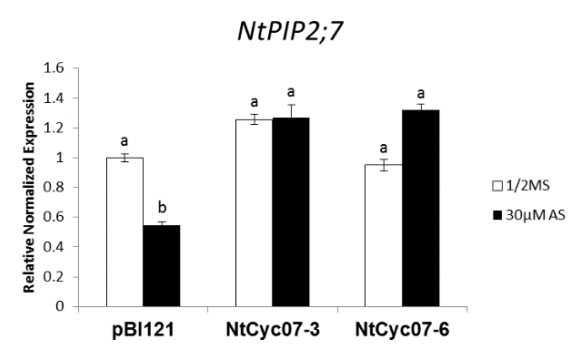

(i)

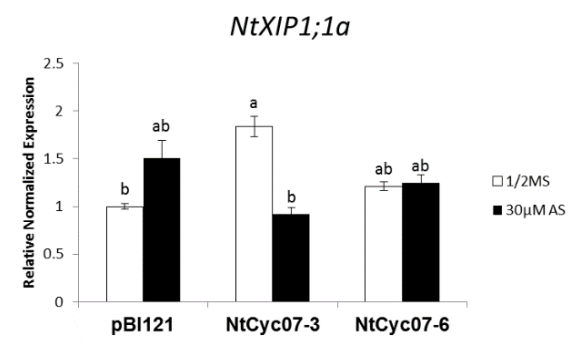

$(\mathbf{k})$

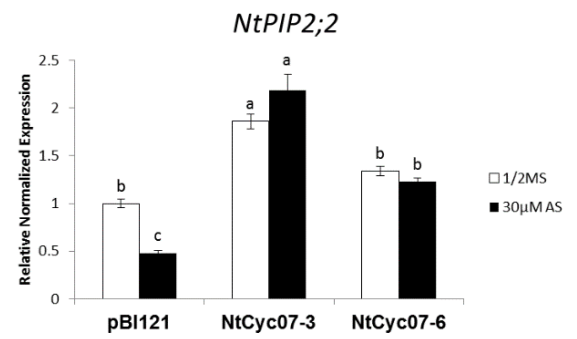

(h)

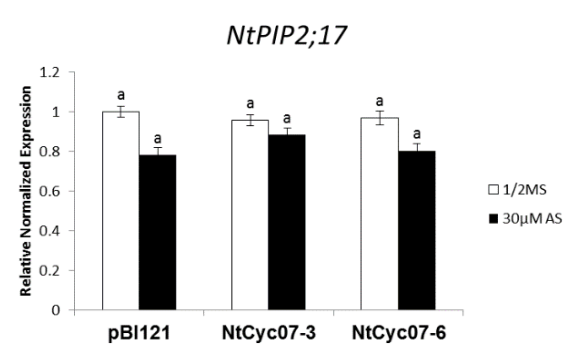

(j)

NtXIP2;1

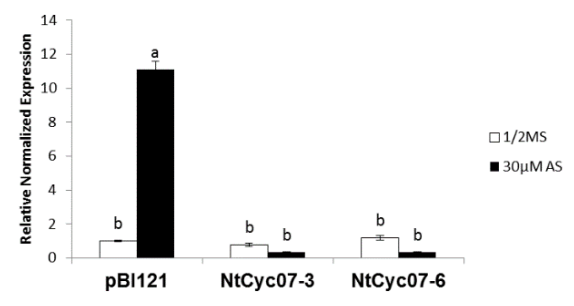

(1)

Figure 2. Relative expression levels (in quantitative RT-PCR—qRT-PCR) of As(III) transporters in NtCyc07-tobacco. qRT-PCR analysis showing the expression levels of (a) NtNIP1;1 (XP_016487110.1), (b) NtNIP2;1 (XP_016451246.1), (c) NtNIP3;1 (XP_016460638.1), (d) NtNIP4;1 (XP_016486634.1), (e) NtPIP1;1 (NP_001313131.1), (f) NtPIP1;5 (AAB81601.1), (g) NtPIP2;1 (AF440272.1), (h) NtPIP2;2 (NM_001325404.1), (i) NtPIP2;7 (NP_001313061.1), (j) NtPIP2;17 (NP_001312464.1), (k) NtXIP1;1 $\alpha$ (NP_001312796) and (1) NtXIP2;1 (XP_016489264.1) in control ( $p$ BI121) and transgenic (NtCyc07) tobacco. Total RNA was isolated from tobacco seedlings grown for 3 weeks on 1/2 MS agar media supplemented without or with $30 \mu \mathrm{M}$ sodium arsenite. 1/2 MS indicates a control (no As(III) treatment). The data are averages of three independent experiments per each treatment, and error bars indicate standard errors (S.E.). Different letters over columns indicate significant differences $(p \leq 0.05)$ between treatments.

As shown in Figure 2e-j, among PIPs which do not have As specificity based on SDP [30], expressions of PIP1;1, PIP1;5, PIP2;1, PIP2;2, and PIP2;7 were higher in NtCyc07-tobacco than in control plants, while PIP2;17 expression did not show a difference from that of control tobacco. Therefore, it is assumed that PIP1;1, PIP1;5, PIP2;1, PIP2;2, and PIP2;7 are involved in decreasing As(III) accumulation by higher activity of As(III) efflux in transgenic tobacco.

In addition, we examined expression levels of two XIP in response to As(III) since XIP was not characterized yet [30]. As shown in Figure 2k,l, XIP1;1 $\alpha$ expression level in $\mathrm{NtCyc07-tobacco} \mathrm{was}$ not different from that of control plants, while the expression level of XIP2;1 was lower in transgenic tobacco than in control plants. This suggests that XIP2;1 may have a higher activity of As(III) influx, therefore its reduced expression contributes to the lower level of $\mathrm{As}$ (III) in $\mathrm{NtCyc07-expressing} \mathrm{tobacco.}$

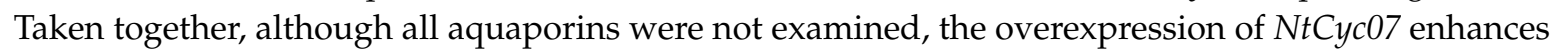
the expressions of putative As(III) exporter NIP1;1, PIP1;1, PIP1;5, PIP2;1, PIP2;2, and PIP2;7, while it 
reduces the expression of putative As(III) importer NIP3;1, NIP4;1, and XIP2;1, contributing to the reduced accumulation of $\mathrm{As}(\mathrm{III})$ in $\mathrm{NtCyc07-overexpressing} \mathrm{tobacco.} \mathrm{However,} \mathrm{gene} \mathrm{expressions} \mathrm{do}$ not reflect exactly protein amounts and activities, thus it is possible that the involvement and role of presented transporters in As(III) transport may be different from our assumption.

Regarding the involvement of aquaporin in As(III) transport, many NIPs and PIPs have been reported: all these have As(III) import activity, and some (AtNIP5;1, AtNIP6;1, OsNIP2;1, OsNIP3;2, LjNIP5;1, LiNIP6;1, OsPIP2;4, OsPIP2;6, and OsPIP2;7) have both import and export activities. In contrast, the participation of aquaporin in As(III) transport has never been reported in tobacco. Therefore, our study is the first report showing the role of aquaporin in As(III) transport in tobacco. However, until the As(III) import/export activity of tobacco NIPs and PIPs are experimentally proved using oocyte injection or thermodynamic kinetics of As uptake/efflux in plants, our data about roles of NIPs and PIPs in As(III) transport are indirect or assumptive.

\subsection{NtCyc07-Expressing Tobacco Displayed a Lower Oxidative Stress and Higher Activities of Antioxidant Enzymes in Response to As(III)}

Since As(III) treatments generally induce oxidative stress [47], we compared oxidative stress levels including hydrogen peroxide $\left(\mathrm{H}_{2} \mathrm{O}_{2}\right)$, superoxide $\left(\mathrm{O}_{2}{ }^{-}\right)$and malondialdehyde (MDA, indicator of membrane oxidation) between control and $\mathrm{NtCyc07-tobacco}$ (Figure 3a-c). While levels of $\mathrm{H}_{2} \mathrm{O}_{2}$, superoxide and MDA were enhanced by $\mathrm{As}(\mathrm{III})$ in control tobacco, those were not altered in $\mathrm{NtCyc07-tobacco,} \mathrm{resulting} \mathrm{in} \mathrm{lower} \mathrm{oxidative} \mathrm{stress} \mathrm{levels} \mathrm{in} \mathrm{transgenic} \mathrm{tobacco} \mathrm{than} \mathrm{in} \mathrm{control}$ plants. In addition, levels of $\mathrm{H}_{2} \mathrm{O}_{2}$ and superoxide were visualized by DAB and NBT staining, respectively (Figure 3d,e). It also confirmed lower contents of $\mathrm{H}_{2} \mathrm{O}_{2}$ and superoxide in transgenic tobacco, compared with that of control plants. Considering the lower levels of As(III) and oxidative stress in $\mathrm{NtCyc07-tobacco,} \mathrm{the} \mathrm{lower} \mathrm{oxidative} \mathrm{stress} \mathrm{may} \mathrm{be} \mathrm{attributed} \mathrm{to} \mathrm{the} \mathrm{lower} \mathrm{As(III)} \mathrm{level.}$

In general, antioxidant enzymes ameliorate oxidative stress; therefore, the activities of catalase (CAT), superoxide dismutase (SOD) and glutathione reductase (GR) were examined (Figure 4). While the activities of all three enzymes were enhanced by As(III) in $\mathrm{NtCyc07-tobacco,} \mathrm{those} \mathrm{of} \mathrm{control} \mathrm{plants}$ were not induced, leading to the higher activities of antioxidant enzymes in $\mathrm{NtCyc07-tobacco} \mathrm{than}$ in control plants. Regarding the lower As(III) level and higher activities of antioxidant enzymes in $\mathrm{NtCyc07-tobacco,} \mathrm{the} \mathrm{higher} \mathrm{antioxidant} \mathrm{enzyme} \mathrm{activity} \mathrm{may} \mathrm{be} \mathrm{ascribed} \mathrm{to} \mathrm{the} \mathrm{lower} \mathrm{content} \mathrm{of}$ $\mathrm{As}(\mathrm{III})$. However, it is also possible that the activity of antioxidant enzyme is enhanced by $\mathrm{NtCyc07}$ itself, in addition to the lower As(III) content. Based on these results, it appears that the lower level of oxidative stress in $\mathrm{NtCyc07-expressing} \mathrm{tobacco} \mathrm{under} \mathrm{As(III)} \mathrm{stress} \mathrm{is} \mathrm{ascribed} \mathrm{to} \mathrm{the} \mathrm{higher} \mathrm{activities} \mathrm{of}$ antioxidant enzymes and the lower level of As(III), when compared with control plants.

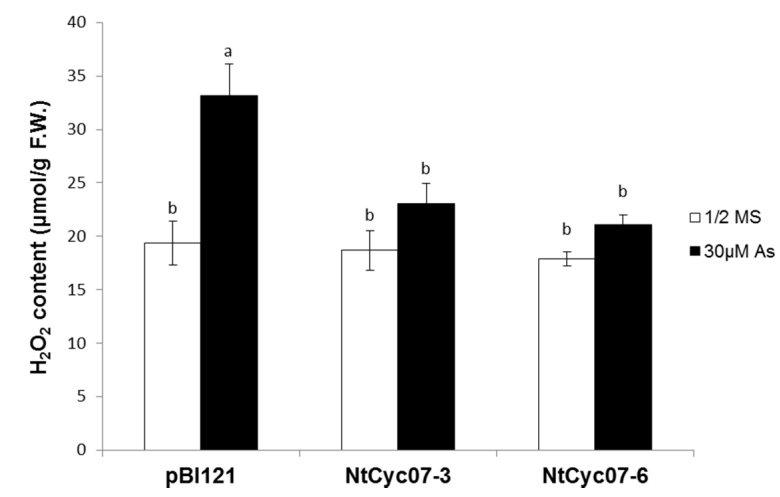

(a)

Figure 3. Cont. 


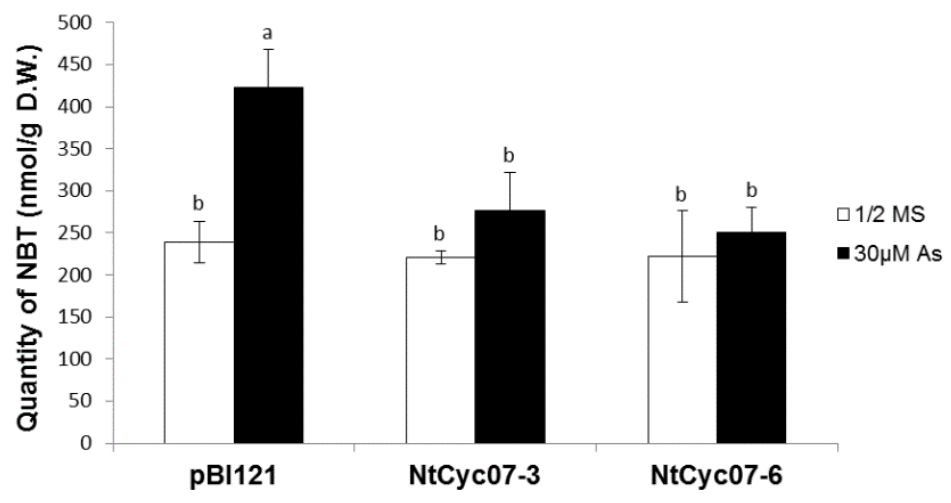

(b)

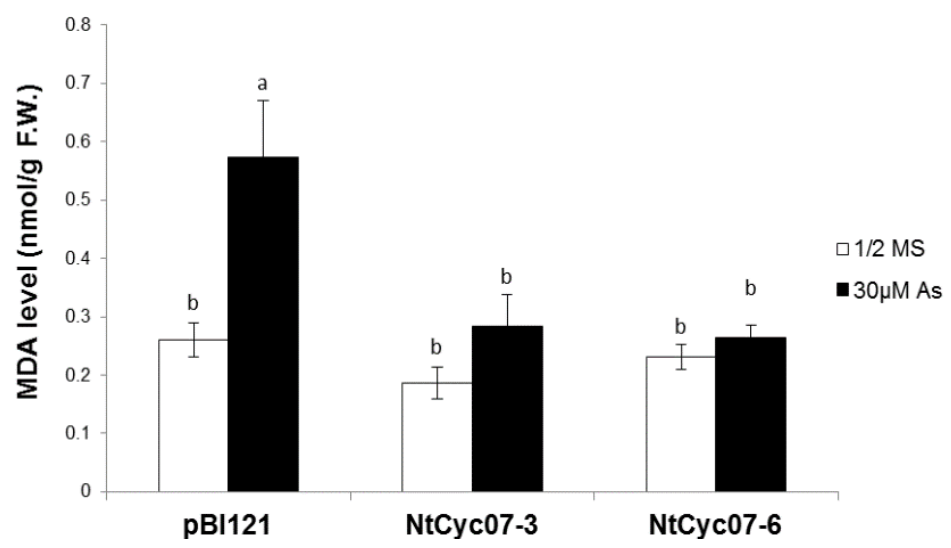

(c)

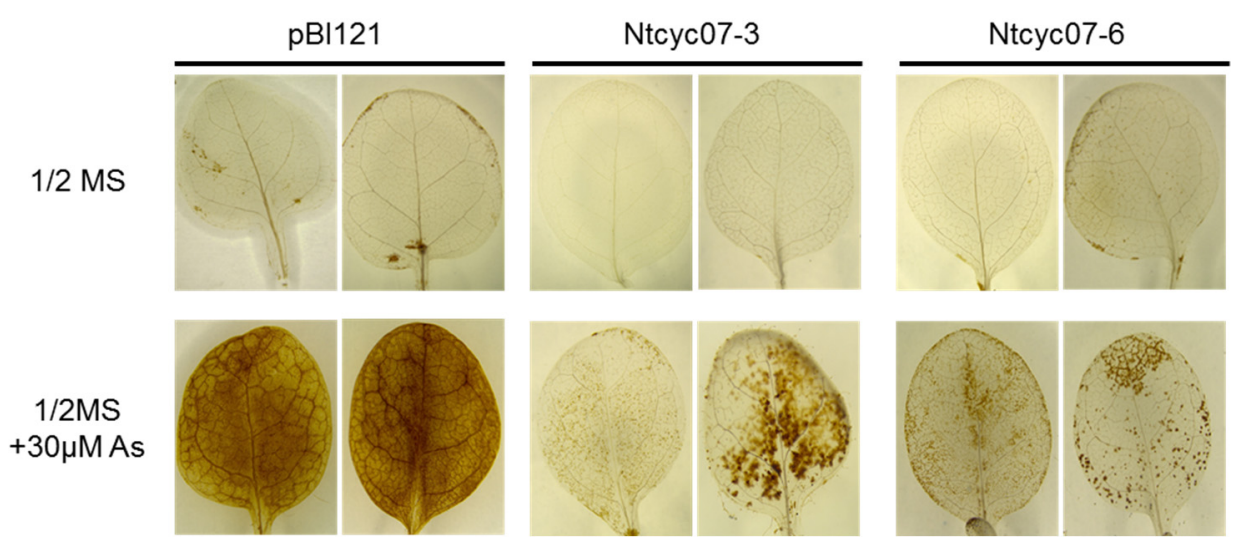

(d)

Figure 3. Cont. 


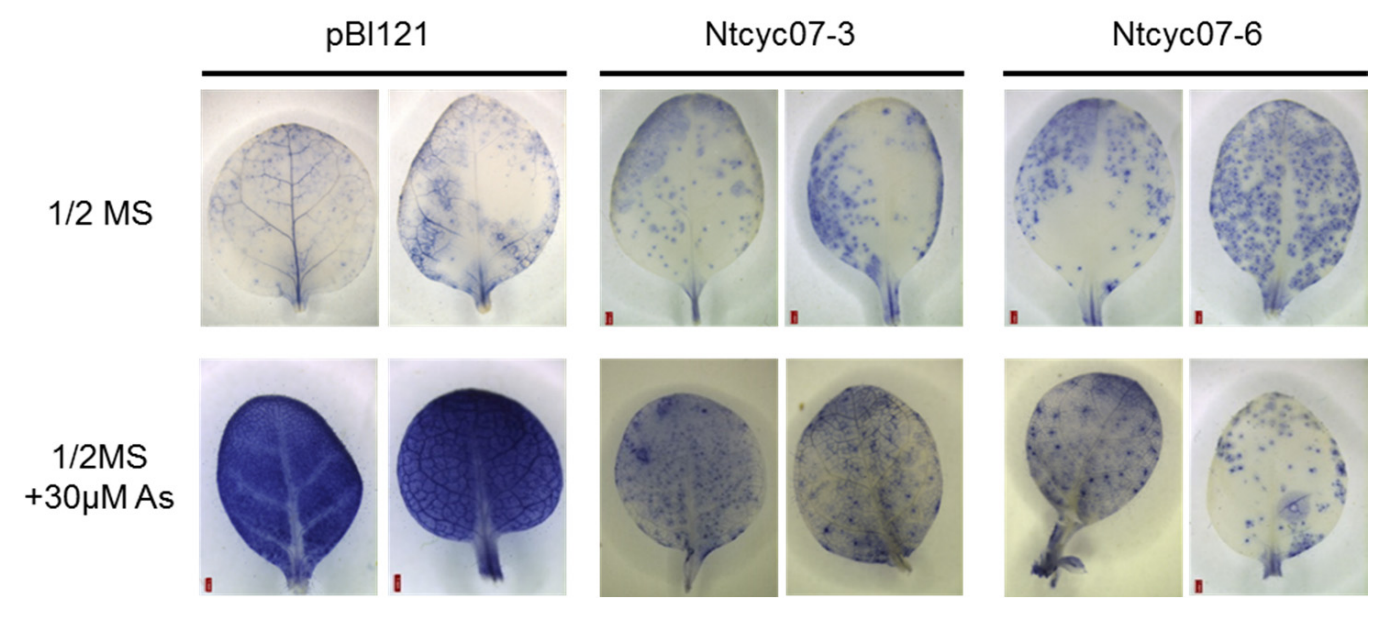

(e)

Figure 3. Oxidative stress levels of $\mathrm{NtCyc07-overexpressing} \mathrm{tobacco} \mathrm{in} \mathrm{response} \mathrm{to} \mathrm{As(III).} \mathrm{Levels} \mathrm{of}$ (a) hydrogen peroxide, (b) superoxide, (c) malondialdehyde (MDA), (d) DAB (3,3-diaminobenzidine) staining for $\mathrm{H}_{2} \mathrm{O}_{2}$ and (e) nitro blue tetrazolium (NBT) staining for superoxide in control (pBI121) and

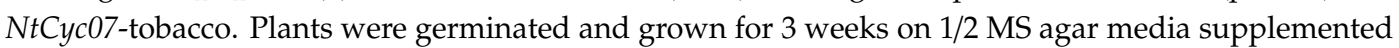
without or with $30 \mu \mathrm{M}$ As(III). 1/2 MS indicates a control (no As(III) treatment). The data are averages of three independent experiments per each treatment, and error bars indicate standard errors (S.E.). Different letters over columns indicate significant differences $(p \leq 0.05)$ between treatments.

In support of our results, it has been reported that plants with reduced oxidative stress/higher activities of antioxidant enzymes show enhanced metal tolerances. Exogenous application of methyl jasmonate increased a Cd tolerance by reducing Cd-induced oxidative stress in rice [48]. Trehalose treatment increased a $\mathrm{Cu}$ tolerance by reducing oxidative stress in rice [49]. The overexpression of tobacco PIC1 (Permease In Chloroplast 1) in tobacco enhanced Cd tolerances and activities of antioxidant enzymes [38]. Application of maleic acid increased $\mathrm{Cr}$ tolerances and activities of antioxidant enzymes and reduced oxidative stress in Brassica juncea [50]. Transgenic tobacco overexpressing tobacco $U B C 1(\mathrm{Ub}$-conjugating protein 1$)$ displayed enhanced $\mathrm{Cd}$ tolerance and reduced oxidative stress [42]. Overexpression of tobacco $U B Q 2$ (Ub-extension protein 2) in tobacco and Arabidopsis increased Cd tolerances and reduced oxidative stress levels [45]. Overexpression of tobacco $\mathrm{Hb} 1$ (non-symbiotic class 1 hemoglobin 1) increased Cd tolerances and decreased oxidative stress in Arabidopsis [40]. Transgenic Arabidopsis overexpressing miRNA156 displayed higher metal tolerance, lower ROS level and higher activities of antioxidant enzymes [46].

Regarding how NtCyc07 modulates expressions of NIPs and PIPs and activities of antioxidant enzymes, it is postulated that $\mathrm{NtCyc07}$ may interact with transcription factors for NIPs, PIPs, and genes of antioxidant enzymes. This may be supported by the report that $\mathrm{NtCyc} 07$ interacts with ACR1 which is a transcription factor of $A C R 3$ (arsenite exporter) in yeast [33]. In addition, it cannot be excluded that $\mathrm{NtCyc} 07$ may modulate protein amounts and activities of transporters and antioxidant enzymes. 


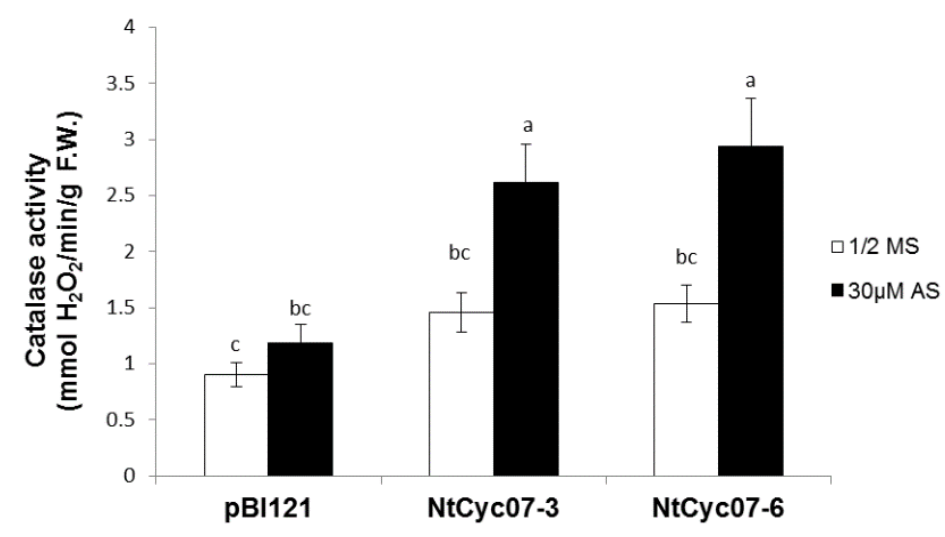

(a)

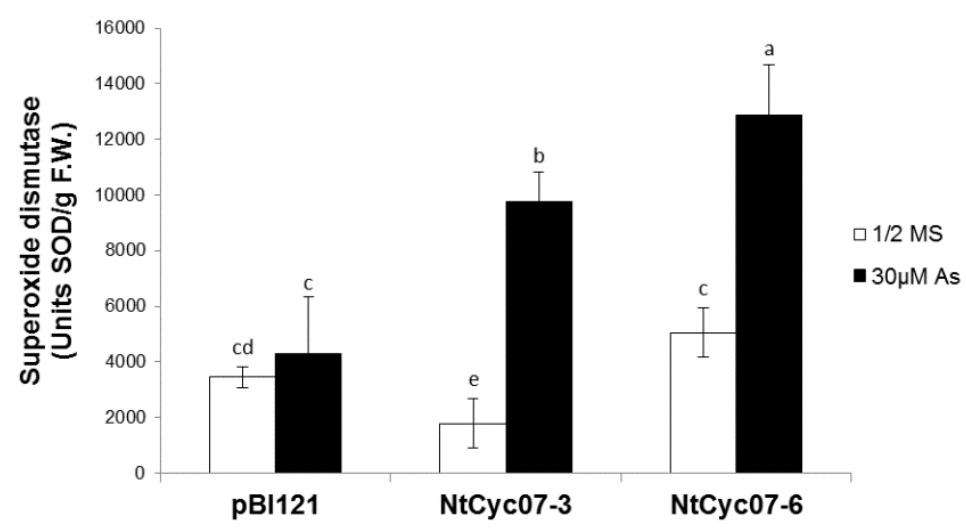

(b)

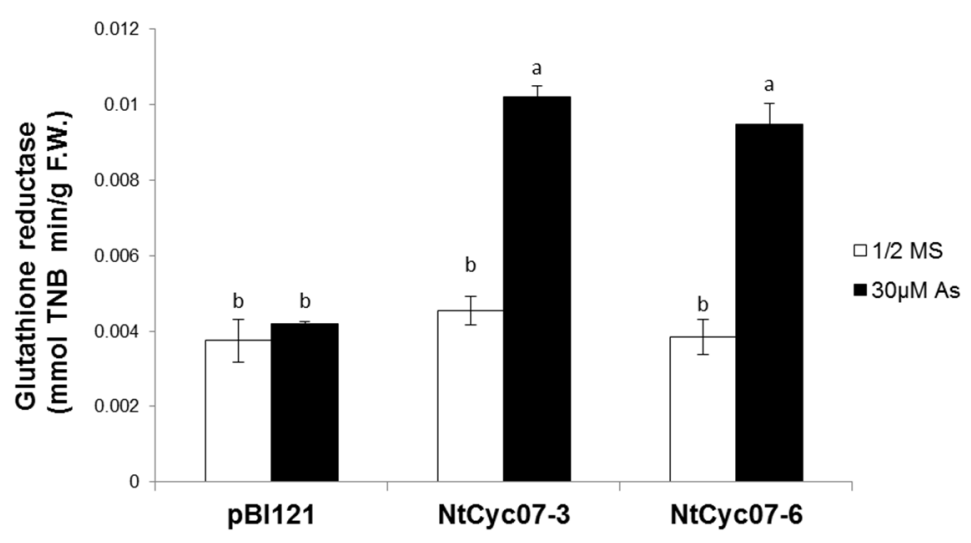

(c)

Figure 4. Activities of antioxidant enzymes in response to As(III) in $\mathrm{NtCyc07-expressing} \mathrm{tobacco.}$ Activities of (a) catalase, (b) superoxide dismutase and (c) glutathione reductase in control (pBI121) and $\mathrm{NtCyc07-tobacco.} \mathrm{Plants} \mathrm{were} \mathrm{germinated} \mathrm{and} \mathrm{grown} \mathrm{for} 3$ weeks on 1/2 MS agar media without or with $30 \mu \mathrm{M} \mathrm{As}(\mathrm{III}) .1 / 2 \mathrm{MS}$ indicates a control (no As(III) treatment). The data are averages of three independent experiments per each treatment, and error bars indicate standard errors (S.E.). Different letters over columns indicate significant differences $(p \leq 0.05)$ between treatments. 


\section{Materials and Methods}

\subsection{Plants}

In this study, we used the previously reported transgenic tobacco (Nicotiana tabacum) lines which overexpress a vector only ( $p B I 121)$ and $\mathrm{NtCyc07} \mathrm{(NtCyc07-3} \mathrm{and} \mathrm{-6)} \mathrm{after} \mathrm{harvesting} \mathrm{new} \mathrm{seeds} \mathrm{[34].}$ Tobacco seeds were sterilized, vernalized, germinated, and grown for 3 weeks on half-strength Murashige and Skoog medium (MS medium, pH 5.7) with or without $30 \mu \mathrm{M}$ sodium arsenite. The plates were placed in a growth chamber under a $16 \mathrm{~h}$ light (cool white fluorescent light at $150 \mathrm{mmol} / \mathrm{m}^{2} / \mathrm{s}$ ) $/ 8 \mathrm{~h}$ dark photoperiod and $23 / 21^{\circ} \mathrm{C}$ of day/night temperatures.

\subsection{As(III) Tolerance and Accumulation}

Arsenite tolerance was measured as described in the previous paper [34]. The As(III) tolerance rate $(\%)$ was calculated by dividing the fresh weights of the As(III) treated plants $(n=30)$ by the fresh weights of the control plants. To analyze the As(III) accumulation, control (pBI121) and transgenic (NtCyc07) tobacco seedlings grown for 3 weeks on agar media containing $30 \mu \mathrm{M}$ As(III) were harvested, washed three times with ice-cold $5 \mathrm{mM} \mathrm{CaCl}_{2}$ and dried for $72 \mathrm{~h}$ at $60^{\circ} \mathrm{C}$. The dried sample $(1 \mathrm{~g})$ was digested with concentrated $\mathrm{HNO}_{3}$ and $\mathrm{HClO}_{4}$ in a Teflon Digestion Vessel (Savillex, Eden Prairie, MN, USA). The As(III) concentration was measured in triplicate using Inductively Coupled Plasma-Atomic Emission Spectroscopy (ICP-AES, Perkin Elmer Optima 4300 DV, San Diego, CA, USA) at a wavelength of $188.98 \mathrm{~nm}$ at The National Instrumentation Center for Environmental Management (NICEM, Seoul, Korea).

\subsection{Quantitative Real Time PCR ( $q R T-P C R)$}

RNA isolation, cDNA synthesis, and qRT-PCR were performed as previously described [51]. Total RNA was isolated from 3 week-old $100 \mathrm{mg}$ seedlings using gDNA removal column and RNA binding column in IQeasy ${ }^{\mathrm{TM}}$ Plus plant RNA extraction mini kit (iNtRON biotechnology, Seongnam, Korea). cDNA was synthesized from $2 \mu \mathrm{g}$ of total RNA using NEXscript ${ }^{\mathrm{TM}} \mathrm{RT} 2 \mathrm{X}$ master mix Oligo dT (NEX Diagnostics, Seongnam, Korea). Quantitative RT-PCR was performed using a CFX Connect ${ }^{\mathrm{TM}}$ Real-Time PCR Detection System (Bio-Rad Laboratories Inc., Hercules, CA, USA). Each $20 \mu \mathrm{L}$ reaction mixture contains $10 \mu \mathrm{L}$ of SYBER Supermix (SsoAdvanced ${ }^{\mathrm{TM}}$ Universal SYBR $®$ Green Supermix, Bio-Rad, Hercules, CA, USA), $7 \mu \mathrm{L}$ of nuclease-free water, $1 \mu \mathrm{L}$ of cDNA, and $1 \mu \mathrm{L}$ of gene specific primers. The qRT-PCR reaction conditions were $95^{\circ} \mathrm{C}$ for $30 \mathrm{~s}, 40$ cycles at $95^{\circ} \mathrm{C}$ for $15 \mathrm{~s}$, and $60^{\circ} \mathrm{C}$ for $20 \mathrm{~s}$. Experiments were performed in triplicate (three biological repeats), and each run contained three technical replicates for the cDNA and each primer set. Relative transcript levels were normalized to the internal quantitative control NtActin (ACCESSION \#U60495.1), and the relative expression level of each gene was calculated using the 2- $\Delta \Delta \mathrm{Ct}$ method [52]. The gene-specific primers are presented in Supplementary Materials Table S1, and the MIQE check list for qRT-PCR is presented in Supplementary Materials Table S2.

\subsection{Analysis of Antioxidant Enzyme Activity}

\subsubsection{Sample Preparation}

Leaf $(0.2 \mathrm{~g})$ of tobacco seedlings grown for 3 weeks on $1 / 2 \mathrm{MS}$ agar media with or without $30 \mu \mathrm{M}$ As(III) was ground in liquid nitrogen, homogenized in $1.2 \mathrm{~mL}$ of potassium phosphate buffer $(0.2 \mathrm{M}$, $\mathrm{pH}$ 7.8) containing $0.1 \mathrm{mM}$ EDTA, and centrifuged for $20 \mathrm{~min}$ at $15,000 \times g, 4{ }^{\circ} \mathrm{C}$. Then, the supernatant was stored at $-80^{\circ} \mathrm{C}$ until using it for the enzyme assay.

\subsubsection{Measurement of Antioxidant Enzyme Activity}

Catalase (CAT; 1.11.1.6) activity was measured as previously described [53]. The reaction was initiated by adding $15 \mu \mathrm{L}$ of leaf extract to $2.5 \mu \mathrm{L} \mathrm{H}_{2} \mathrm{O}_{2}$ (30\% solution) prepared in $1 \mathrm{~mL} 50 \mathrm{mM}$ of 
potassium phosphate buffer ( $\mathrm{pH}$ 7.5) in a final volume of $1 \mathrm{~mL}$. The extinction coefficient of $\mathrm{H}_{2} \mathrm{O}_{2}$ $\left(40 \mathrm{M}^{-1} \mathrm{~cm}^{-1}\right.$ at $240 \mathrm{~nm}$ ) was used to calculate the enzyme activity (millimoles of $\mathrm{H}_{2} \mathrm{O}_{2}$ per minute per gram fresh weight).

Activity of superoxide dismutase (SOD; EC 1.15.1.1) was determined using the modified NBT method [54]. The assay mixture contained $50 \mathrm{mM}$ phosphate buffer ( $\mathrm{pH} 7.8$ ) with $2 \mathrm{mM}$ EDTA, $1 \mathrm{mM}$ riboflavin, $9.9 \mathrm{mM}$ L-methionine, $0.025 \%$ Triton-X100 and $55 \mu \mathrm{M}$ NBT. After adding $40 \mu \mathrm{L}$ of leaf extract to $2 \mathrm{~mL}$ of reaction mixture, the reaction was started by illuminating the reaction mixture with a fluorescent lamp $(15 \mathrm{~W})$ for $10 \mathrm{~min}$. The absorbance of the reaction mixture was measured at $560 \mathrm{~nm}$. The reaction mixture without the leaf extract was used as a control. The enzyme activity (per gram fresh weight) of the sample was calculated based on the standard curve of pure SOD.

Glutathione reductase activity (GR; EC 1.8.1.7) was determined as described by Smith et al. [55]. The reaction mixture $(1 \mathrm{~mL})$ contained $10 \mu \mathrm{L}$ of leaf extract, $100 \mathrm{mM}$ potassium phosphate buffer (pH 7.5), $0.1 \mathrm{mM} \mathrm{NADPH}, 0.75 \mathrm{mM}$ DTNB (2-nitrobenzoic acid), and $1 \mathrm{mM}$ GSSG (glutathione disulfide). The reaction was initiated by addition of GSSG, and the absorbance at $412 \mathrm{~nm}$ was measured after 3 min when DTNB was reduced to TNB (2-nitro-5-thiobenzoate). The extinction coefficient of TNB $\left(14.15 \mathrm{M}^{-1} \mathrm{~cm}^{-1}\right)$ was used to calculate the GR activity (millimoles of TNB per minute per gram fresh weight). All enzyme experiments were performed in triplicate, and each enzyme activity was measured three times.

\subsection{Measurement of Oxidative Stress}

Hydrogen peroxide $\left(\mathrm{H}_{2} \mathrm{O}_{2}\right)$, superoxide $\left(\mathrm{O}_{2}^{-}\right)$and malondialdehyde (MDA) were quantified in tobacco seedlings grown for 3 weeks on 1/2 MS agar plates as previously described [56-58]. For hydrogen peroxide measurement, $0.3 \mathrm{~g}$ of leaf was ground in liquid nitrogen, homogenized with $5 \mathrm{~mL}$ of $0.1 \%$ trichloroacetic acid (TCA), centrifuged for $15 \mathrm{~min}$ at $12,000 \times \mathrm{g}, 4{ }^{\circ} \mathrm{C}$, and the supernatant was collected. The reaction mixture contained $0.5 \mathrm{~mL}$ of leaf extract supernatant, $0.5 \mathrm{~mL}$ of $10 \mathrm{mM}$ potassium phosphate buffer ( $\mathrm{pH} 7.0)$, and $1 \mathrm{~mL}$ of $1 \mathrm{M}$ potassium iodide. The same reaction mixture lacking the leaf extract was used as a blank. The concentration of $\mathrm{H}_{2} \mathrm{O}_{2}$ was determined based on a standard curve of known concentrations of $\mathrm{H}_{2} \mathrm{O}_{2}$.

To measure the concentration of $\mathrm{O}_{2}{ }^{-}, 100 \mathrm{mg}$ of leaf was ground to a fine powder in liquid nitrogen, homogenized in $2 \mathrm{~mL}$ of $50 \mathrm{mM}$ potassium phosphate buffer ( $\mathrm{pH7.8)}$, and centrifuged for $10 \mathrm{~min}$ at $4{ }^{\circ} \mathrm{C}, 10,000 \times \mathrm{g}$. Then, $1 \mathrm{~mL}$ of the supernatant was mixed with $0.9 \mathrm{~mL}$ of $50 \mathrm{mM}$ potassium phosphate buffer (pH 7.8) and $0.1 \mathrm{~mL}$ of $10 \mathrm{mM}$ hydroxylamine hydrochloride, and then incubated for $20 \mathrm{~min}$ at $25^{\circ} \mathrm{C}$. Subsequently, $1 \mathrm{~mL}$ of $17 \mathrm{mM}$ sulfonilamide and $1 \mathrm{~mL}$ of $7 \mathrm{mM} \alpha$-naphthylamine were added to the incubation mixture, further incubated under the same condition, and the absorbance was measured at $530 \mathrm{~nm}$. The generation of $\mathrm{O}_{2}{ }^{-}$was calculated based on a standard curve of $\mathrm{NO}_{2}{ }^{-}$(nitrite).

For the measurement of MDA, $0.5 \mathrm{~g}$ of tobacco seedlings was ground in liquid nitrogen, homogenized with $1.5 \mathrm{~mL}$ of $20 \%(w / v)$ TCA, and centrifuged for $5 \mathrm{~min}$ at $10,000 \times g .2 \mathrm{~mL}$ of thiobarbituric acid solution $(0.5 \%(w / v)$ in $20 \%$ TCA) was added to $1 \mathrm{~mL}$ of the supernatant, incubated at $95^{\circ} \mathrm{C}$ for $15 \mathrm{~min}$, quickly cooled in an ice bath, and centrifuged at $12,000 \times \mathrm{g}$ for $10 \mathrm{~min}$. The absorbance of the supernatant was measured at 450, 532 and $600 \mathrm{~nm}$. The concentration of MDA was determined according to the following formula: concentration $\left(\mu \mathrm{mol} \mathrm{L}^{-1}\right)=6.45 \times\left(\mathrm{OD}_{532}-\mathrm{OD}_{600}\right)-0.56 \times \mathrm{OD}_{450}$ (OD: optical density). For all measurements, three independent experiments were performed.

\subsection{Visualization of $\mathrm{H}_{2} \mathrm{O}_{2}$ and Superoxide $\left(\mathrm{O}_{2}^{-}\right)$}

$\mathrm{H}_{2} \mathrm{O}_{2}$ was visually detected in tobacco leaves as previously described [59]. Leaves of 3-week-old plants grown on 1/2 MS agar media were immersed and infiltrated under a vacuum with $1.25 \mathrm{mg} \mathrm{mL}^{-1}$ 3,3'-diaminobenzidine (DAB) (D8001, Sigma-Aldrich, St. Louis, MO, USA) staining solution ( $\mathrm{pH} 3.8)$, and incubated at $25^{\circ} \mathrm{C}$ for $8 \mathrm{~h}$. Subsequently, stained leaves were bleached in acetic acid-glycerol-ethanol $(1 / 1 / 3)(v / v / v)$ solution for $5 \mathrm{~min}$ at $100^{\circ} \mathrm{C}$, preserved in glycerol-ethanol $(1 / 4)(v / v)$ solution, and photographed. $\mathrm{H}_{2} \mathrm{O}_{2}$ was visualized as a deep brown color due to $\mathrm{DAB}$ polymerization. 
For each experiment, at least 10 plants were examined per line, and three independent experiments were performed.

$\mathrm{O}_{2}^{-}$(superoxide radical) was visually detected by nitro blue tetrazolium (NBT) (N6639, Sigma-Aldrich) staining using the modified method [60]. Briefly, leaves were detached and vacuum-infiltrated for $15 \mathrm{~min}$ in $1 \mathrm{mg} \mathrm{mL}^{-1} \mathrm{NBT}$ solution prepared in $10 \mathrm{mM}$ potassium phosphate buffer (pH 7.8) containing $10 \mathrm{mM} \mathrm{NaN}_{3}$ (sodium azide), incubated for $3 \mathrm{~h}$ at $25{ }^{\circ} \mathrm{C}$, bleached as described above, and photographed. The production of $\mathrm{O}_{2}{ }^{-}$was visualized as a blue color due to NBT precipitation. For each experiment, 10 plants were examined per line, and three independent experiments were performed.

\subsection{Statistical Analysis}

Two-way ANOVA was used to analyze the data using SAS software (version 9.1). The means were separated by Tukey's multiple comparison test with significant differences at $p \leq 0.05$.

\section{Conclusions}

1. The overexpression of $\mathrm{NtCyc07}$ enhances $\mathrm{As}(\mathrm{III})$ tolerance by decreasing $\mathrm{As}(\mathrm{III})$ accumulation through the increased expression of putative As(III) exporter NIP1;1, PIP1;1, PIP1;5, PIP2;1, PIP2;2, and PIP2;7, and the reduced expression of putative As(III) importer NIP3;1, NIP4;1, and XIP2;1.

2. $\mathrm{NtCyc07-tobacco}$ displays lower levels of oxidative stress and higher activities of antioxidant enzymes. The lower oxidative stress in $\mathrm{NtCyc07-tobacco}$ may be attributed to the higher activities of antioxidant enzymes and the lower level of As(III). The higher activities of antioxidant enzymes in $\mathrm{NtCyc07-tobacco}$ may be ascribed to the lower content of As(III) and probably the direct effect/function of $\mathrm{NtCyc07.}$

Supplementary Materials: The following are available online at http://www.mdpi.com/2223-7747/9/11/1480/s1, Table S1: List of the primer sequences used in this study, Table S2: The MIQE check list for qRT-PCR.

Author Contributions: S.H. designed and supervised whole research, and wrote the article with contributions of all the authors; D.K. and R.B. equally performed all experiments; M.M. contributed to data analysis. All authors have read and agreed to the published version of the manuscript.

Funding: This work was funded by the Korea Institute of Planning and Evaluation for Technology in Food, Agriculture, Forestry and Fisheries (IPET) through the Agri-Bio industry Technology Development Program, funded by Ministry of Agriculture, Food and Rural Affairs (MAFRA) (IPET 319107-4), and by the New breeding technologies development Program (Project No. PJ014770022020), Rural Development Administration, Korea.

Conflicts of Interest: The authors declare no conflict of interest.

\section{References}

1. Vahidnia, A.; van der Voet, G.B.; de Wolff, F.A. Arsenic neurotoxicity-A review. Hum. Exp. Toxicol. 2007, 26, 823-832. [CrossRef]

2. Naujokas, M.F.; Anderson, B.; Ahsan, H.; Aposhian, H.V.; Graziano, J.H.; Thompson, C.; Suk, W.A. The broad scope of health effects from chronic arsenic exposure: Update on a worldwide public health problem. Environ. Health Perspect. 2013, 121, 295-302. [CrossRef] [PubMed]

3. Ratnaike, R.N. Acute and chronic arsenic toxicity. Postgrad. Med. J. 2003, 79, 391-396. [CrossRef] [PubMed]

4. Singh, A.P.; Goel, R.K.; Kaur, T. Mechanisms pertaining to arsenic toxicity. Toxicol. Int. 2011, 18, 87-93.

5. Smith, A.H.; Hopenhayn-Rich, C.; Bates, M.N.; Goeden, H.M.; Hertz-Picciotto, I.; Duggan, H.M.; Wood, R.; Kosnett, M.J.; Smith, M.T. Cancer risks from arsenic in drinking water. Environ. Health Perspect. 1992, 97, 259-267. [CrossRef]

6. Gebel, T.W. Genotoxicity of arsenical compounds. Int. J. Hyg. Environ. Health 2001, 203, 249-262. [CrossRef]

7. Tseng, C.H.; Chong, C.K.; Tseng, C.P.; Hsueh, Y.M.; Chiou, H.Y.; Tseng, C.C.; Chen, C.J. Long-term arsenic exposure and ischemic heart disease in arseniasis-hyperendemic villages in Taiwan. Toxicol. Lett. 2003, 137, 15-21. [CrossRef] 
8. Chiou, H.Y.; Huang, W.I.; Su, C.L.; Chang, S.F.; Hsu, Y.H.; Chen, C.J. Dose-response relationship between prevalence of cerebrovascular disease and ingested inorganic arsenic. Stroke 1997, 28, 1717-1723. [CrossRef]

9. Hendryx, M. Mortality from heart, respiratory, and kidney disease in coal mining areas of Appalachia. Int. Arch. Occup. Environ. Health 2009, 82, 243-249. [CrossRef]

10. Kile, M.L.; Christiani, D.C. Environmental arsenic exposure and diabetes. JAMA 2008, 300, $845-846$. [CrossRef]

11. Bienert, G.P.; Thorsen, M.; Schussler, M.D.; Nilsson, H.R.; Wagner, A.; Tamas, M.J.; Jahn, T.P. A subgroup of plant aquaporins facilitate the bi-directional diffusion of as(oh)3 and sb(oh)3 across membranes. BMC Biol. 2008, 6, 26. [CrossRef]

12. Verbruggen, N.; Hermans, C.; Schat, H. Mechanisms to cope with arsenic or cadmium excess in plants. Curr. Opin. Plant. Biol. 2009, 12, 364-372. [CrossRef] [PubMed]

13. Isayenkov, S.V.; Maathuis, F.J.M. The Arabidopsis thaliana aquaglyceroporin atnip7;1 is a pathway for arsenite uptake. Febs. Lett. 2008, 582, 1625-1628. [CrossRef] [PubMed]

14. Maurel, C. Plant aquaporins: Novel functions and regulation properties. Febs. Lett. 2007, 581, $2227-2236$. [CrossRef]

15. Uehlein, N.; Lovisolo, C.; Siefritz, F.; Kaldenhoff, R. The tobacco aquaporin ntaqp1 is a membrane co2 pore with physiological functions. Nature 2003, 425, 734-737. [CrossRef]

16. Bienert, G.P.; Moller, A.L.B.; Kristiansen, K.A.; Schulz, A.; Moller, I.M.; Schjoerring, J.K.; Jahn, T.P. Specific aquaporins facilitate the diffusion of hydrogen peroxide across membranes. J. Biol. Chem. 2007, 282, 1183-1192. [CrossRef]

17. Bienert, G.P.; Schussler, M.D.; Jahn, T.P. Metalloids: Essential, beneficial or toxic? Major intrinsic proteins sort it out. Trends Biochem. Sci. 2008, 33, 20-26. [CrossRef]

18. Dynowski, M.; Mayer, M.; Moran, O.; Ludewig, U. Molecular determinants of ammonia and urea conductance in plant aquaporin homologs. FEBS Lett. 2008, 582, 2458-2462. [CrossRef]

19. Maurel, C.; Verdoucq, L.; Luu, D.T.; Santoni, V. Plant aquaporins: Membrane channels with multiple integrated functions. Annu Rev. Plant. Biol. 2008, 59, 595-624. [CrossRef]

20. Wu, B.; Song, J.; Beitz, E. Novel channel enzyme fusion proteins confer arsenate resistance. J. Biol. Chem. 2010, 285, 40081-40087. [CrossRef] [PubMed]

21. Ma, J.F.; Yamaji, N.; Mitani, N.; Xu, X.Y.; Su, Y.H.; McGrath, S.P.; Zhao, F.J. Transporters of arsenite in rice and their role in arsenic accumulation in rice grain. Proc. Natl. Acad. Sci. USA 2008, 105, 9931-9935. [CrossRef]

22. Kamiya, T.; Fujiwara, T. Arabidopsis nip1;1 transports antimonite and determines antimonite sensitivity. Plant Cell Physiol. 2009, 50, 1977-1981. [CrossRef] [PubMed]

23. Zhao, X.Q.; Mitani, N.; Yamaji, N.; Shen, R.F.; Ma, J.F. Involvement of silicon influx transporter osnip2;1 in selenite uptake in rice. Plant Physiol. 2010, 153, 1871-1877. [CrossRef]

24. Katsuhara, M.; Sasano, S.; Horie, T.; Matsumoto, T.; Rhee, J.; Shibasaka, M. Functional and molecular characteristics of rice and barley nip aquaporins transporting water, hydrogen peroxide and arsenite. Plant Biotechnol. Nar. 2014, 31, 213-219. [CrossRef]

25. Xu, W.; Dai, W.; Yan, H.; Li, S.; Shen, H.; Chen, Y.; Xu, H.; Sun, Y.; He, Z.; Ma, M. Arabidopsis nip3;1 plays an important role in arsenic uptake and root-to-shoot translocation under arsenite stress conditions. Mol. Plant 2015, 8, 722-733. [CrossRef]

26. Chen, Y.; Han, Y.H.; Cao, Y.; Zhu, Y.G.; Rathinasabapathi, B.; Ma, L.Q. Arsenic transport in rice and biological solutions to reduce arsenic risk from rice. Front. Plant Sci. 2017, 8, 268. [CrossRef]

27. Kamiya, T.; Tanaka, M.; Mitani, N.; Ma, J.F.; Maeshima, M.; Fujiwara, T. Nip1;1, an aquaporin homolog, determines the arsenite sensitivity of Arabidopsis thaliana. J. Biol. Chem. 2009, 284, 2114-2120. [CrossRef] [PubMed]

28. Chen, Y.; Sun, S.K.; Tang, Z.; Liu, G.D.; Moore, K.L.; Maathuis, F.J.M.; Miller, A.J.; McGrath, S.P.; Zhao, F.J. The nodulin 26-like intrinsic membrane protein osnip3;2 is involved in arsenite uptake by lateral roots in rice. J. Exp. Bot. 2017, 68, 3007-3016. [CrossRef]

29. Mosa, K.A.; Kumar, K.; Chhikara, S.; Mcdermott, J.; Liu, Z.J.; Musante, C.; White, J.C.; Dhankher, O.P. Members of rice plasma membrane intrinsic proteins subfamily are involved in arsenite permeability and tolerance in plants. Transgenic Res. 2012, 21, 1265-1277. [CrossRef]

30. Ahmed, J.; Mercx, S.; Boutry, M.; Chaumont, F. Evolutionary and predictive functional insights into the aquaporin gene family in the allotetraploid plant Nicotiana tabacum. Int. J. Mol. Sci. 2020, 21, 4743. [CrossRef] 
31. Kodama, H.; Ito, M.; Hattori, T.; Nakamura, K.; Komamine, A. Isolation of genes that are preferentially expressed at the $\mathrm{g}(1) / \mathrm{s}$ boundary during the cell cycle in synchronized cultures of Catharanthus roseus cells. Plant Physiol. 1991, 95, 406-411. [CrossRef]

32. Ito, M.; Kodama, H.; Komamine, A. Identification of a novel s-phase-specific gene during the cell-cycle in synchronous cultures of Catharanthus roseus cells. Plant J. 1991, 1, 141-148. [CrossRef] [PubMed]

33. Mok, Y.G.; Lee, B.D.; Kim, Y.J.; Lee, C.E.; Kim, D.G.; Lee, J.; Shim, J.; Meng, Y.; Rosen, B.P.; Choi, J.S.; et al. The tobacco gene ntcyc07 confers arsenite tolerance in saccharomyces cerevisiae by reducing the steady state levels of intracellular arsenic. Febs. Lett. 2008, 582, 916-924. [CrossRef] [PubMed]

34. Lee, M.S.; Hwang, S. Cyc07 enhances arsenite tolerance by reducing as levels in Nicotiana tabacum and Arabidopsis thaliana. Plant Biotechnol. Rep. 2012, 6, 391-395. [CrossRef]

35. Kim, Y.J.; Chang, K.S.; Lee, M.R.; Kim, J.H.; Lee, C.E.; Jeon, Y.J.; Choi, J.S.; Shin, H.S.; Hwang, S.B. Expression of tobacco cdna encoding phytochelatin synthase promotes tolerance to and accumulation of cd and as in saccharomyces cerevisiae. J. Plant. Biol. 2005, 48, 440-447. [CrossRef]

36. Lee, B.D.; Hwang, S. Tobacco phytochelatin synthase (ntpcs1) plays important roles in cadmium and arsenic tolerance and in early plant development in tobacco. Plant Biotechnol. Rep. 2015, 9, 107-114. [CrossRef]

37. Gasic, K.; Korban, S.S. Expression of Arabidopsis phytochelatin synthase in indian mustard (Brassica juncea) plants enhances tolerance for cd and zn. Planta 2007, 225, 1277-1285. [CrossRef]

38. Gong, X.; Yin, L.W.; Chen, J.Q.; Guo, C.H. Overexpression of the iron transporter ntpic1 in tobacco mediates tolerance to cadmium. Plant Cell Rep. 2015, 34, 1963-1973. [CrossRef]

39. Lee, B.R.; Hwang, S. Over-expression of nthb1 encoding a non-symbiotic class 1 hemoglobin of tobacco enhances a tolerance to cadmium by decreasing no (nitric oxide) and cd levels in Nicotiana tabacum. Environ. Exp. Bot. 2015, 113, 18-27. [CrossRef]

40. Bahmani, R.; Kim, D.; Na, J.; Hwang, S. Expression of the tobacco non-symbiotic class 1 hemoglobin gene $\mathrm{hb} 1$ reduces cadmium levels by modulating cd transporter expression through decreasing nitric oxide and ros level in Arabidopsis. Front. Plant Sci. 2019, 10, 201. [CrossRef]

41. Li, Q.H.; Li, Y.; Wu, X.Y.; Zhou, L.; Zhu, X.J.; Fang, W.P. Metal transport protein 8 in camellia sinensis confers superior manganese tolerance when expressed in yeast and Arabidopsis thaliana. Sci. Rep. UK 2017, 7, 39915. [CrossRef] [PubMed]

42. Bahmani, R.; Kim, D.; Lee, B.D.; Hwang, S. Over-expression of tobacco ubc1 encoding a ubiquitin-conjugating enzyme increases cadmium tolerance by activating the $20 \mathrm{~s} / 26$ s proteasome and by decreasing cd accumulation and oxidative stress in tobacco (Nicotiana tabacum). Plant Mol. Biol. 2017, 94, 433-451. [CrossRef]

43. Sheng, Y.; Yan, X.; Huang, Y.; Han, Y.; Zhang, C.; Ren, Y.; Fan, T.; Xiao, F.; Liu, Y.; Cao, S. The WRKY transcription factor, WRKY13, activates pdr8 expression to positively regulate cadmium tolerance in Arabidopsis. Plant Cell Environ. 2019, 42, 891-903. [CrossRef]

44. Qiao, K.; Wang, F.; Liang, S.; Wang, H.; Hu, Z.; Chai, T. Improved cd, Zn and Mn tolerance and reduced cd accumulation in grains with wheat-based cell number regulator tacnr2. Sci. Rep. 2019, 9, 870. [CrossRef] [PubMed]

45. Bahmani, R.; Modareszadeh, M.; Kim, D.; Hwang, S. Overexpression of tobacco ubq2 increases cd tolerance by decreasing cd accumulation and oxidative stress in tobacco and Arabidopsis. Environ. Exp. Bot. 2019, 166, 103805. [CrossRef]

46. Zhang, L.; Ding, H.; Jiang, H.L.; Wang, H.S.; Chen, K.X.; Duan, J.J.; Feng, S.J.; Wu, G. Regulation of cadmium tolerance and accumulation by mir156 in Arabidopsis. Chemosphere 2020, 242, 125168. [CrossRef]

47. Mishra, S.; Jha, A.B.; Dubey, R.S. Arsenite treatment induces oxidative stress, upregulates antioxidant system, and causes phytochelatin synthesis in rice seedlings. Protoplasma 2011, 248, 565-577. [CrossRef]

48. Singh, I.; Shah, K. Exogenous application of methyl jasmonate lowers the effect of cadmium-induced oxidative injury in rice seedlings. Phytochemistry 2014, 108, 57-66. [CrossRef]

49. Mostofa, M.G.; Hossain, M.A.; Fujita, M.; Tran, L.S.P. Physiological and biochemical mechanisms associated with trehalose-induced copper-stress tolerance in rice. Sci. Rep. UK 2015, 5, 11433. [CrossRef] [PubMed]

50. Mahmud, J.A.; Hasanuzzaman, M.; Nahar, K.; Rahman, A.; Hossain, M.S.; Fujita, M. Maleic acid assisted improvement of metal chelation and antioxidant metabolism confers chromium tolerance in Brassica juncea $\mathrm{L}$. Ecotoxicol. Environ. Saf. 2017, 144, 216-226. [CrossRef] [PubMed] 
51. Kim, D.; Bahmani, R.; Ko, J.H.; Hwang, S. Development of bisphenol a (bpa)-sensing indicator arabidopsis thaliana which synthesizes anthocyanin in response to bpa in leaves. Ecotox. Environ. Safe. 2019, 170, 627-634. [CrossRef]

52. Pfaffl, M.W. A new mathematical model for relative quantification in real-time rt-PCR. Nucleic Acids Res. 2001, 29, e45. [CrossRef]

53. Aebi, H. Catalase in vitro. Methods Enzymol. 1984, 105, 121-126.

54. Beyer, W.F., Jr.; Fridovich, I. Assaying for superoxide dismutase activity: Some large consequences of minor changes in conditions. Anal. Biochem. 1987, 161, 559-566. [CrossRef]

55. Smith, I.K.; Vierheller, T.L.; Thorne, C.A. Assay of glutathione reductase in crude tissue homogenates using 5,5'-dithiobis(2-nitrobenzoic acid). Anal. Biochem. 1988, 175, 408-413. [CrossRef]

56. Lei, Y.B.; Yin, C.Y.; Li, C.Y. Differences in some morphological, physiological, and biochemical responses to drought stress in two contrasting populations of Populus przewalskii. Physiol. Plant. 2006, 127, 182-191. [CrossRef]

57. Loreto, F.; Velikova, V. Isoprene produced by leaves protects the photosynthetic apparatus against ozone damage, quenches ozone products, and reduces lipid peroxidation of cellular membranes. Plant Physiol. 2001, 127, 1781-1787. [CrossRef]

58. Lv, W.T.; Lin, B.; Zhang, M.; Hua, X.J. Proline accumulation is inhibitory to Arabidopsis seedlings during heat stress. Amino Acids 2011, 41, S69. [CrossRef]

59. Fryer, M.J.; Oxborough, K.; Mullineaux, P.M.; Baker, N.R. Imaging of photo-oxidative stress responses in leaves. J. Exp. Bot. 2002, 53, 1249-1254.

60. Rao, M.V.; Davis, K.R. Ozone-induced cell death occurs via two distinct mechanisms in Arabidopsis: The role of salicylic acid. Plant J. 1999, 17, 603-614. [CrossRef]

Publisher's Note: MDPI stays neutral with regard to jurisdictional claims in published maps and institutional affiliations. 